\title{
Impacts of Mobile Media on the Efficiency of Learning English for Special Purposes in Health Students
}

\author{
Mahmood Atharizadeh \\ Department of English Language, Kashan University of Medical Sciences, Kashan, Iran \\ E-mail: m.atharizadeh@yahoo.com
}

Received: September 22, 2017 Accepted: December 22, 2017 Published: December 27, 2017

doi: $10.5296 /$ jsss.v5i1.12373

URL: http://doi.org/10.5296/jsss.v5i1.12373

\begin{abstract}
With amazing speed of cyberspace, the internet, tablet, and mobile applications, they have been widely used also in education. Moreover, their availability in language learning and teaching has become very diverse so that their integration into traditional methods in language learning is significantly taken into account. The aim of the survey is to study the students' overviews of impacts of mobile media language learning in better and more efficient learning of English for Special Purposes (ESP) among public and occupational health students studying in Kashan University of Medical Sciences, Iran.
\end{abstract}

Keywords: Mobile media, ESP, Public and occupational health students

\section{Introduction}

In the real world, there are no real geographical borders and boundaries, and in virtual communities, spatial and temporal boundaries are entirely symbolic. Symbolic boundaries and resources are all fodder for the imagination of what a given community consists of and can be, as well as the kind of interaction that this new type of engagement reflects (Wesley \& Renninger, 2004). Additionally, the physical "brick and mortal" classroom is starting to lose its monopoly as the place of learning. The Internet and World Wide Web have made significant changes to almost all aspects of our lives ranging from a global economy, personal, and professional networks to sources of information, news, and learning (Tuan, 2015).

Similarly, Cyberspace has found a significant status in everyday lives. It is used as a multiple purposes tools for various applications range from information acquisition to language learning and teaching as well as daily communication.

With the skyrocket development of information communication technology (ICT), mobile and tablet have not only been used in communication, but also in language learning and teaching among students and teachers alike. Their fascinating application as well as portable 


\section{Macrothink}

tools and easy availability have willingly increased operators tendencies toward using them. The range of technologies now available can support learners and teachers in a variety of ways both inside the classroom and in the outside such as home environment and dormitory as well as while the learners are on the move about their daily lives. Moreover, in the fast pace of modern life, students and instructors would appreciate using constructively some spare time that they may have, in order to work on lessons at any place, even when away from offices, classrooms and labs where computers are usually located (Darrell, 2013).

Students can now work with data analysis tools, collaborative learning environment, simulations, multimedia authoring tools, and virtual environment, all of which offer access to new content and new ways of learning.

So, in recent years, the Internet has made online learning possible, and many researchers and educators are interested in online learning to enhance and improve student learning outcomes while combating the reduction in resources (Tuan, 2015). Most colleges and universities are today willing to invest in electronic media for creating an autonomous electronic learning environment to help student learn foreign languages easily and efficiently. This has made a tremendous growth of (ICT) across the broad in recent years. Many countries have invested in ICT in educational fields (Maria, 2005).

\section{Literature Review}

\subsection{Mobile Media as a Tool-assisted Language Learning}

Increased development in technology coupled with a range of needs and expectations from a range of stakeholders have made it imperative for educational organizations to constantly upgrade their strategies and policies in teaching and learning as a way to remain effective and competitive (Maria, 2005).

Digital media has been used to enhance language learning for decades. Since the aim of language learning is to develop communicative proficiency, using communication devices and channels that already exist in the classroom is a sensible way of exploiting opportunities for language practice. The 'anywhere, anytime' accessibility to educational contents that mobile short messaging systems (SMSs), sometimes freely, offer users, means that mobile learning can extend the opportunities for study outside of the classroom (Asgari, 2016).

Cyberspace tool-assisted language learning refers to techniques, approaches or actions that help students in their learning process. Undoubtedly, media and communication technologies play a significant role in our daily lives. Today, wireless technologies surround people and are increasingly becoming integrated into every waking moments and a part of individuals' lifestyle.

Nowadays, digital literacy is also particularly significant, as children are bombarded daily by an array of digital texts, and it is particularly important that they learn to understand the nuance of media types that surround them in the physical world as well as on the internet. So, Internet is socially applied knowledge and it is social conditions which make the cultural difference in how it is applied (Maria, 2004).

And now, students are consulting their mobile devices more than their teachers. If they cannot find what they are looking for on the screens, then they ask for their teachers' help. The practicality, mobility, and the accessibility of the mobile devices inevitably create this situation 
(Sinem, 2016).

In addition, it is able to support a variety of learning activities and students are also ready to use it for learning.

Digital literacy can encompass a variety of English learning activities as well as ESP and meet specific needs of learners. For applying and using it by students efficiently, a more specially designed English course module should be developed to enhance their medical English proficiency (Asgari, 2014). So, easy and cheap accessibility of wireless technologies demands educational authorities to make them accessible for learners.

\subsection{Technology and Education}

There is now little doubt that the World Wide Web is the most successful educational tool to have appeared in a long time (Yousef \& Hamideh, 2013). Furthermore, it is evident that technology has changed the world of communication dramatically, and its impact on human everyday and professional life as well as learning and educational systems is mounting. Mobile learning represents a way to address a number of our educational problems. Devices such as smart phones and tablets enable innovation and help students, teachers, and parents gain access to digital content and personalized assessment vital for a post-industrial world (Darrell, 2013).

The social aspect of interaction of digital communication tools can lead the learners to language development. Applying them can also facilitate learning and make them easier for learners to exchange their classmates' learning experiences even to students from different parts of the world especially through telecollaboration. In fact, technology and education have a tightly intertwined future. Therefore, the increase in investment in ICT by education departments around the world has been documented Slaouti et.al.

\subsection{Mobile Applications (Apps)}

Mobile-assisted language learning (MALL) is language learning that is assisted or enhanced through the use of a handheld mobile device. MALL is a subset of both Mobile Learning (m-learning) and computer-assisted language learning (CALL). MALL has evolved to support students' language learning with the increased use of mobile technologies such as mobile phones (cell phones).

Mobile applications are another necessary aspect of our daily lives." Smart devices (both phones and tablets) feature dedicated software applications that can be used to assist language learning. Many apps have the more specific purpose of helping to develop reading and writing (Samsiah \& Azidah, 2013).

Table 1. Students' answers

\begin{tabular}{lll}
\hline & ITEM & PERCENT \\
\hline 1 & Students' knowledge & $(68.80 \%)$ \\
2 & Time Assigned & $2-3$ hours daily \\
3 & Impact of Mobile Media & $(64.5 \%)$ \\
4 & Willing Toward Using Mobile Media & $(70 \%)$ \\
5 & Motivation in Using Mobile Media & $(60.2 \%)$ \\
\hline
\end{tabular}


Therefore, Mobile Assisted Language Learning (MALL) has emerged in the modern era of education.

It is one of the most interesting emerging types of technology enhanced learning, especially now that mobile devices are daily carried out by more and more people and that the mobile phone has evolved from simple voice device to a multimedia communication tools capable of downloading and uploading text, data, audio, video. Mobile phones spread globally is unmatched in the history of technology (Samsiah \& Azidah, 2013).

\section{Research Design}

\subsection{Participants}

In this study, 86 Iranian public and occupational students, including 26 (30.23\%) males and 60 $(69.76 \%)$ females, studying ESP in the second year were participated in Kashan University of Medical Sciences, IRAN,. They had their English classes in their college, where Students should follow their educational curriculum, select suitable exercises and communicate with peers and teachers through traditional methods.

\subsection{Data Collection and Analysis}

Questionnaire is one of the most common research methods. So, a questionnaire was designed to study the impacts of cyberspace tool-assisted language learning in better and more efficient understanding of ESP among public and occupational students studying in Kashan University of Medical Sciences. It consisted of 16 multiple questions in four fields including: students' knowledge, time assigned to use media, impact of mobile media as a tool-assisted language learning, and students' willing as well as three open-ended ones.

A descriptive method was used to analyze the questions. In order to make the study accurate, before the investigation, the teacher makes it clear to the participants that the questionnaire would have no influence on their academic achievement and honest responses would be very important for this analysis. It took the participants about 15 minutes to complete the questionnaires. After the completion, they were collected at once by the teacher for data analysis.

\section{Discussion}

As stated in table 1of 86 students, 80 students (68.80\%) were aware of impacts of mobile and electronic media. When they were asked how much time they spend using them daily, the average time was 2-3 hours per day. Concerning the impact of mobile and electronic media on English language learning 75 (64.5\%) students agreed they have strong impacts on learning. And $82(70 \%)$ students showed their willing toward using them provided the sufficient ground is paid by their teachers and college. Concerning their motivation in using mobile and electronic media (e.g. mobile and tablet) for doing class activities and homework as a part of ESP educational curriculum, $70(60.2 \%)$ answered they strongly agree given the suitable environment. For designing and implementing the curriculum, they agreed and presented their readiness because they believed it can enhance learning ESP. Therefore; provided the proper ground, there will be great tendencies and willingness among some students in using mobile media on better learning ESP.

\section{Opportunities and challenges}

Should opportunities, tendency, and willingness are provided by teachers and students alike 
for applying mobile media as a tool-assisted language learning for learning and better understanding ESP, they pay the ground for easy and efficient learning and understanding. However, some obstacles such as limitation of sources and financial supports make applying them difficult for both teachers and students.

\section{Pedagogical Implication}

From the above investigation and analysis, it is evident that there are some tendencies and willingness among students in using cyberspace tool-assisted and mobile autonomous learning in ESP. However, implementing these electronic media demand some strategies.

First, changing the culture of learners and teachers contributes an important role in teaching and learning a foreign language by new technologies emerged in the world of communication and Information Technology. So, the appropriate ground should be prepared by educational authorities. Second, college foreign language teachers should design a sufficient pedagogical curriculum when they are going to train ESP. Then, teachers should try to know learners' strategy use at the beginning of the course, and help learners to know their strategy use and encourage them to try to use it. Third, college foreign language teachers should improve learners' awareness of using the social/affective strategies in their reading performance. Students should be encouraged to attend various English reading and writing activities. Teachers should help them learn how to cooperate with others and become more confident. Finally, college foreign language teachers should try to provide various reading materials and create a variety of suitable activities for students. In this way, students may improve their ESP comprehension and make great progress as soon as possible.

\section{Conclusion}

Advanced mobiles and tablets are available for students so that they are now using them for multiple purposes. And since the trend in Iran's Medical sciences Universities and the Ministry of medical Educations alike is increasingly moving toward virtual, online ,or blended learning, more researches are needed to pave the way for encouraging students toward the new educational system and implementing the new learning strategies.

Provided the financial supports by academic authorities and a more precisely designed English course modules are performed, students will be more encouraged to use mobile media for better learning English for special purposes. Accordingly, more precise studies are suggested for designing such educational curriculum and approaches to encourage both teachers and students to use them for improving their teaching and learning.

\section{References}

Asgari, A. J. (2014). A Blended - Learning Setting in English for Medical Purposes Course Incorporating. International Journal of Language and Linguistics, 1(2).

Asgari, A. J. (2016). Mobile Educational SMSs as Supplementary Means to Teach Sentence Paraphrasing in EMP Course. International Journal of Interactive Mobile Technologies.

Darrell, M. W. (2013). Mobile Learning: Transforming Education, Engaging Students, and Improving Outcomes, DM West - Brookings Policy Report, scienceisaverb.com

Eric, C. Learning, research, and Design of mobile educational games. Cambridge Massachusetts London, England. 


\section{Macrothink}

Journal of Social Science Studies

ISSN 2329-9150 2018, Vol. 5, No. 1

Maria, D. (2004). ICT Implications in a Learning Setting, University of Porto, p. 68.

Maria, V. (2005). Eythimios Alepis. Computers \& Education, 44(1), 53-68.

Samsiah, B., \& Azidah, A. Z. (2013). Adoption and application of mobile learning in the education industry, 90, 720-729, 6th International Conference on University Learning and Teaching (InCULT 2012).

Sinem, B. (2016). JOURNAL OF EDUCATIONAL AND INSTRUCTIONAL STUDIES IN THE WORLD, 6(1).

Solomon, S. O., Jarkko, S., \& Erkki, S. (2016). M-Learning: A New Paradigm of Learning ICT in Nigeria. International Journal of Interactive Mobile Technologies.

Stanely, G. (2013). Innovations in learning technologies for English language teaching. Edited by GaryMotteram ,London

Tuan, N. (2015). The Effectiveness of Online Learning. MERLOT Journal of Online Learning and Teaching, 11(2).

Wesley, S., \& Renninger, K. A. (2004). Building Virtual Community. Cambridge University Press.

Yousef, M., \& Hamideh, Z. (2013). Mobile Learning for Education: Benefits and Challenges. International Journal of Computational Engineering Research, 03(6).

\section{Copyright Disclaimer}

Copyright for this article is retained by the author(s), with first publication rights granted to the journal.

This is an open-access article distributed under the terms and conditions of the Creative Commons Attribution license (http://creativecommons.org/licenses/by/3.0/). 